\title{
Disseminated Nocardiosis in an Immunocompetent Adult: Diagnostic Challenges
}

\author{
B Saroj Kumar Prusti ${ }^{1}$, Kiran Kumar Ramineni ${ }^{2}$, Amitha Reddy ${ }^{3}$, Majed Abdul Basit Momin ${ }^{4}$, Safina \\ Perveen $^{1}$ \\ ${ }^{1}$ Department of Critical Care, ${ }^{2}$ Department Neurology ${ }^{3}$ Department of Microbiology, ${ }^{4}$ Department of Laboratory \\ Medicine, Yashoda Hospitals, Malakpet, Hyderabad' India
}

\begin{abstract}
Nocardiosis is an opportunistic infection seen in people with impaired host defenses usually cell mediated immunity. It can involve a single organ or present as disseminated infection affecting multiple organ systems. We are reporting a case of 60 year old; an immunocompetent female presented with fever, cough, skin lesions and altered sensorium. Thorough systemic examination coupled with meticulous etiological work up including gram stain, acid fast staining and culture established the definite diagnosis of Nocardiosis. This case highlights the utility of clinical suspicion and early microbiological detection for diagnosing such uncommon condition presenting with common clinical symptoms and multisystem involvement in an immunocompetent patient. J Microbiol Infect Dis 2019; 9(1): 46-50.
\end{abstract}

Keywords: Disseminated Nocardiosis, immunocompetent, microbiological findings

\section{INTRODUCTION}

Nocardiosis is a caused by a soil borne aerobic actinomycete. This may present as localized or disseminated form of infection and commonly introduced via respiratory tract [1]. Nocardia species are gram positive and weakly acid fast. They form filamentous branched cells, which fragment into pleomorphic rod shaped or coccoid elements $[2,3]$.

The genus Nocardia, includes more than 80 species, of which more than 30 have been related to cause pathogenic disease in humans [4]. Pulmonary or disseminated disease occurs predominantly among persons who have deficient cell-mediated immunity e.g., in cases of lymphoma, organ transplant, glucocorticoid therapy or HIV infection with less than 250 CD4+ $\mathrm{T}$ cells/ $\mu \mathrm{L}$. Our case is unique with multiorgan involvement of Nocardiosis in apparently immunocompetent female.

\section{CASE}

The case of 60 year, old female, patient presented with complaints of fever, skin lesions on the trunk and upper limbs for 10 days, cough for 6 days and altered sensorium since two days.
Fever was associated with chills, rigors and headache. Skin lesions first appeared on trunk and then progressed to upper limbs, not associated with itching or pain. Cough was productive with white colored sputum. She was a known hypertensive for the past 4 years and on amlodipine $5 \mathrm{mg}$ once daily. No history of diabetes mellitus, ischemic heart disease, stroke or any other chronic illness. No history of corticosteroid or other immune suppressants usage.

On general examination, at admission she was drowsy and arousable to verbal stimulus. She had tachycardia with regular pulse rate of $122 / \mathrm{min}$, blood pressure $110 / 60 \mathrm{mmHg}$, tachypnoeic with respiratory rate of $25 / \mathrm{min}$ and febrile with axillary temperature of $104{ }^{\circ} \mathrm{F}$.No evidence of pallor, icterus, clubbing and lymphadenopathy. She had multiple macular, maculopapular and nodular lesions over forearms (Figure1 red arrow). Multiple Plaques with central necrosis on abdomen and chest wall (Figure 1 blue arrow).

Central nervous system examination revealed Glasgow Coma Scale of 11 -E3V3M5. No abnormal eyeball movements, no nystagmus.

Correspondence: Dr. Majed Abdul Basit Momin, Department of Laboratory Medicine, Yashoda Hospital, Malakpet, Hyderabad, India 
Pupils were bilateral $3 \mathrm{~mm}$ and reacting to light. No deviation of angle of mouth or tongue. Moving all four limbs off the bed with no asymmetry. All deep tendon reflexes were normal. Plantar reflex was bilateral nonresponsive. Neck stiffness was present. No papilledema on fundus examination. Respiratory system examination revealed bilateral infrascapular crepitations. Cardiovascular and Gastrointestinal system examination was unremarkable.

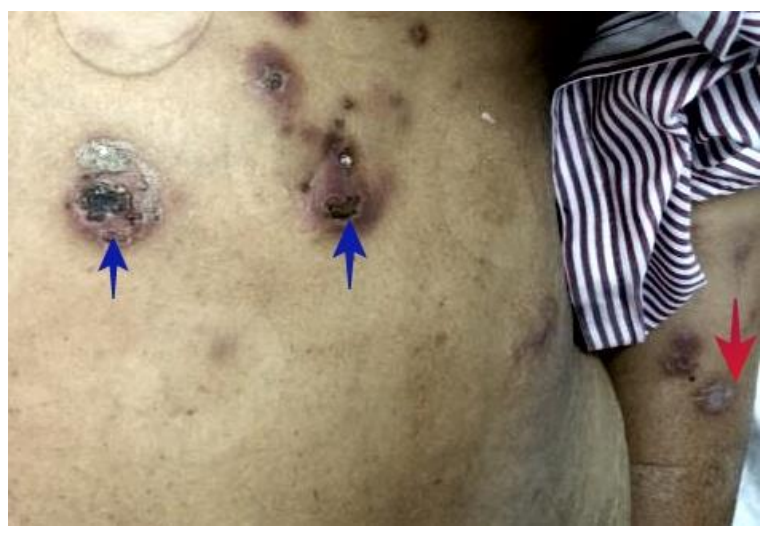

Figure 1. Macular and maculopapular lesion over forearm (red arrow) and multiple plaques with central necrosis on abdomen and lower (blue arrow) chest wall.

Laboratory findings revealed hematological, biochemical, blood gas analysis and serological findings as mentioned in the Table 1. Cerebrospinal fluid analysis revealed pleocytosis with Lymphocytic predominance, details mentioned in the Table 2.

Chest radiograph showed non homogenous nodular infiltrates in both lower zones. HRCT chest revealed bilateral lower lobe nodular lesions and cavitatory lesions in left lower lobe (Figure 2a, b). Magnetic Resonance Imaging of brain (MRI) showed multiple focal areas of restricted diffusion in bilateral Cerebellar hemispheres in Diffusion weighted images. In T2 Flair Multiple focal hyperintense nodular lesions in cerebral, cerebellar hemispheres and brainstem with the largest lesion $(12 \mathrm{~mm}$ diameter) in the left posterior high parietal region (Figure 2c) was seen, T1 Contrast MRI was showing multiple enhancing nodular lesions scattered in bilateral cerebral and cerebellar (Figure 2d), with a ring enhancing lesion in the left posterior high parietal region (Figure 2e).
Gram stain and 1\% Acid-fast stain from pustular skin lesions showed branching, beaded, filamentous bacteria (Figure 3a-Acid fast 1\% stain) suggestive of Nocardia. Pus Culture from Skin lesion showed Chalky White colonies with aerial mycelia, dry pitted colonies (Figure 3b) suggestive of Nocardia. The diagnosis of disseminated Nocardiosis was considered in view of multiple organ involvement including Skin, CNS and Pulmonary system. Drug susceptibility testing and species identification could not be done at our institution. Blood culture after 2 weeks showed colonies of Nocardia.
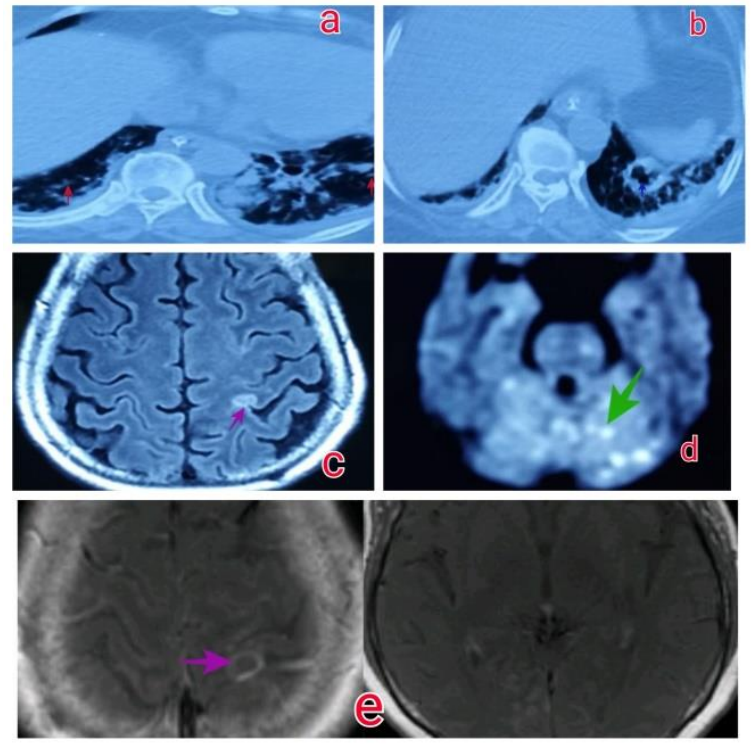

Figure 2-a and b: CT Chest with bilateral lower lobe nodular lesions (red arrow) and cavitatory lesions in left lower lobe (blue arrow); 2-c: Hyperintense nodular lesion left parietal region (red arrow). 2-d: Multiple focal hyperintense nodular lesions in cerebral, cerebellar hemispheres and brainstem. 2-e: T1 Contrast MRI was showing multiple enhancing nodular lesions (pink arrow) scattered in bilateral cerebral and cerebellar with a ring enhancing lesion (pink arrow) in the left posterior high parietal region.

Treatment and course in the hospital: The patient was initially treated with empirical antibiotics with Injection Ceftriaxone $2 \mathrm{gm}$ IV 12 hourly, Injection Vancomycin $1 \mathrm{~g}$ IV per $12 \mathrm{~h}$, and other supportive treatment. On second day after pus Gram stain and $1 \%$ acid fast stain report suggested the diagnosis of Nocardiosis, combination of Trimethoprim + Sulfamethoxazole $(160+800 \mathrm{mg}) 2$ tablets 8 
hourly was added to the regimen along with injection Imepenam with cilastatin $500 \mathrm{mg}$ IV 6 hourly and vancomycin was stopped.

Table 1. CSF parameters of the patient.

\begin{tabular}{|c|c|c|}
\hline CSF Parameter & Observed value & Lab reference range \\
\hline Total leucocyte count & 180 cells $/ \mathrm{mm}^{3}$ & $0-5$ cells $/ \mathrm{mm}^{3}$ \\
\hline Differential count & L 55\%,P 45\% & \\
\hline Sugar(corresponding blood sugar) & $94 \mathrm{mg} / \mathrm{dl}(150 \mathrm{mg} / \mathrm{dl})$ & $40-70 \mathrm{mg} / \mathrm{dl}$ \\
\hline Proteins & $36 \mathrm{mg} / \mathrm{dl}$ & $12-60 \mathrm{mg} / \mathrm{dl}$ \\
\hline Chlorides & $132 \mathrm{meq} / \mathrm{L}$ & $118-138 \mathrm{mg} / \mathrm{dl}$ \\
\hline ADA & $6 \mathrm{IU} / \mathrm{L}$ & $<6 \mathrm{IU} / \mathrm{L}$ \\
\hline India ink for fungal elements & Negative & \\
\hline Gram Stain & No microorganisms seen & \\
\hline Gene Xpert for Mycobacterium tuberculosis & Negative & \\
\hline PCR quantitative for HSV $1 \& 2$ & Negative & \\
\hline Atypical cells & Not seen & \\
\hline
\end{tabular}

Table 2. Laboratory parameters of the patient.

\begin{tabular}{|c|c|c|}
\hline $\begin{array}{l}\text { Laboratory } \\
\text { parameter }\end{array}$ & Observed value & Lab reference \\
\hline Serum Sodium & $138 \mathrm{mmol} / \mathrm{L}$ & $137-145 \mathrm{mmol} / \mathrm{L}$ \\
\hline $\begin{array}{l}\text { Serum } \\
\text { Potassium }\end{array}$ & $4.5 \mathrm{mmol} / \mathrm{L}$ & $3.5-5.1 \mathrm{mmol} / \mathrm{L}$ \\
\hline Serum Chloride & $106 \mathrm{mmol} / \mathrm{L}$ & $98-107 \mathrm{mmol} / \mathrm{L}$ \\
\hline $\begin{array}{l}\text { Serum } \\
\text { Creatinine }\end{array}$ & $1.20 \mathrm{mg} / \mathrm{dl}$ & $0.8-1.5 \mathrm{mg} / \mathrm{dl}$ \\
\hline $\begin{array}{l}\text { Random plasme } \\
\text { glucose }\end{array}$ & 88 mg/dl & $70-150 \mathrm{mg} / \mathrm{dl}$ \\
\hline Hemoglobin & $12 \mathrm{~g} / \mathrm{dl}$ & $13-17 \mathrm{~g} / \mathrm{dl}$ \\
\hline Platelet count & $2.50 \mathrm{lacs} / \mathrm{mm}^{3}$ & $\begin{array}{l}1.5-4.5 \\
\text { lacs/cumm }\end{array}$ \\
\hline $\begin{array}{l}\text { Total leucocyte } \\
\text { count }\end{array}$ & 11,800 cells $/ \mathrm{mm}^{3}$ & $\begin{array}{l}4000-11000 \\
\text { cells/cumm }\end{array}$ \\
\hline ESR & $120 \mathrm{~mm}$ first hour & $\begin{array}{c}0-15 \mathrm{~mm} \text { in first } \\
\text { hour }\end{array}$ \\
\hline $\begin{array}{l}\text { Prothrombin } \\
\text { Time }\end{array}$ & 17.1 secs & $\begin{array}{c}12.9 \text { secs }(11.7- \\
14.1 \text { secs })\end{array}$ \\
\hline Total bilirubin & $0.8 \mathrm{mg} / \mathrm{dl}$ & $0.2-1.3 \mathrm{mg} / \mathrm{dl}$ \\
\hline $\begin{array}{l}\text { Alkaline } \\
\text { Phosphatase }\end{array}$ & 100 & 38-126 Units/L \\
\hline $\begin{array}{l}\text { SGOT } \\
\text { SGPT }\end{array}$ & $\begin{array}{l}31 \\
38\end{array}$ & $\begin{array}{l}\text { 14-60 Units/ L } \\
\text { 9-69 Units/ L }\end{array}$ \\
\hline $\begin{array}{l}\text { Total proteins } \\
\mathrm{HbA} 1 \mathrm{C}\end{array}$ & $\begin{array}{c}6.3 \mathrm{gm} / \mathrm{dl}(3.4 / 2.9) \\
5.3 \%\end{array}$ & $\begin{array}{c}6.3-8.5 \mathrm{gr} / \mathrm{dl} \\
<5.7 \%\end{array}$ \\
\hline $\mathrm{HBsAg}$ & Non-reactive $(0.24)$ & $<1.0$ \\
\hline $\begin{array}{l}\text { HCV Ab } \\
\text { HIV } 1 \& 2 A b\end{array}$ & $\begin{array}{l}\text { Nonreactive }(0.31) \\
\text { Nonreactive }(0.20)\end{array}$ & $\begin{array}{l}<1.0 \\
<1.0\end{array}$ \\
\hline $\begin{array}{l}\text { Serum } \\
\text { Procalcitonin }\end{array}$ & $16.18 \mathrm{ng} / \mathrm{ml}$ & $<0.1 \mathrm{ng} / \mathrm{ml}$ \\
\hline ABG-PH & $\begin{array}{c}7.41 \\
64.41\end{array}$ & $\begin{array}{c}\text { 7.35-7.45 } \\
75-100 \mathrm{mmHa}\end{array}$ \\
\hline $\mathrm{PaO} 2$ & $\begin{array}{c}64 \mathrm{mmHg} \text { on } 3 \mathrm{~L} \\
\text { Oxygen/minute }\end{array}$ & $\begin{array}{l}75-100 \mathrm{mmHg} \\
\text { at room air }\end{array}$ \\
\hline $\begin{array}{l}\mathrm{PaCO} 2 \\
\mathrm{HCO} 3\end{array}$ & $\begin{array}{l}34 \mathrm{mmHg} \\
22 \mathrm{mmol} / \mathrm{L}\end{array}$ & $\begin{array}{l}35-45 \mathrm{mmHg} \\
22-26 \mathrm{mmol} / \mathrm{L}\end{array}$ \\
\hline $\begin{array}{l}\text { CUE - Protein } \\
\text { and Sugar }\end{array}$ & Absent & \\
\hline CUE-Pus cells & 2-4 pus cells/HPF & 0-5/HPF \\
\hline
\end{tabular}

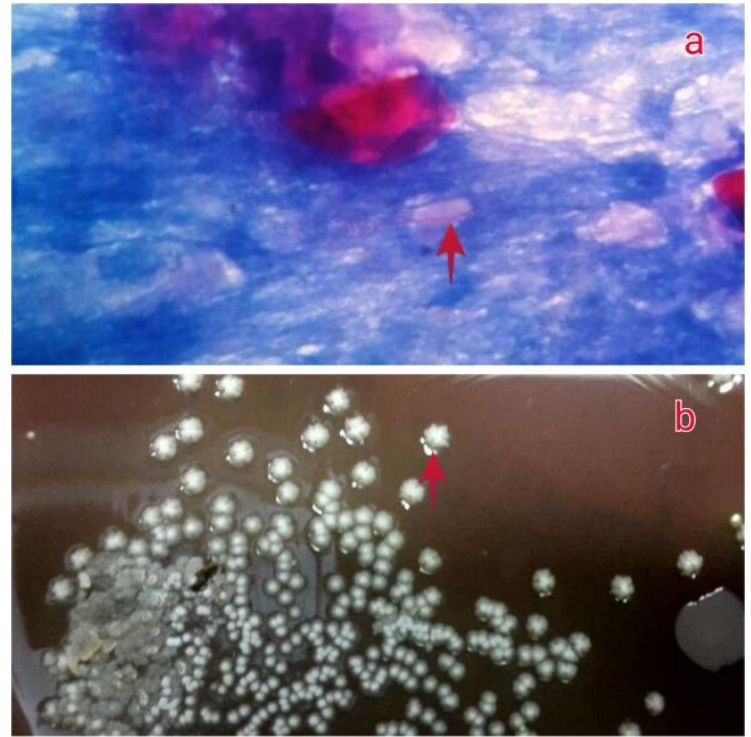

Figure 3: 3a-Acid fast $1 \%$ stain showed partially acid fast branched filamentous bacteria (red arrow). 3bPus Culture from Skin lesion showed Chalky White colonies (red arrow).

After $48 \mathrm{~h}$ pus culture report confirmed the diagnosis, however as the patient's condition progressively worsened, injection Amikacin 1000 mg IV 24 hourly was added. However, in spite of all antibiotics and supportive treatment her general condition deteriorated on fifth day of admission and respiratory distress worsened, required mechanical ventilation. Later she developed hemodynamic instability required vasopressor infusions for hypotension. On 
seventh day she succumbed to disseminated Nocardiosis.

\section{DISCUSSION}

Nocardial infections occur worldwide and are more prevalent in tropical and subtropical environments and its incidence increasing in, India in the recent times. The disease has a more male preponderance due to their habitual working conditions. The disseminated disease is most common in immunocompromised people; three most important factors are HIV infection, chronic lung infection and usage of steroids and other immune-supressants. There were no such predisposing factors found our patient or other history of immunosuppression.

Nocardia are widely distributed in the soil. They are gram positive,slow growing, aerobic filamentous bacteria. The morphology of Nocardia is mimics to Actinomycetes israeli, however the end of the hyphae do not show coliform dilatation and Nocardia are weakly positive for modified kinyouns acid fast staining [4]. Nocardiosis spreads predominantly through respiratory tract. Inhalation of fragmented bacterial mycelia infects lung parenchyma leading to pneumonia or disseminated disease. The characteristic pathological feature of Nocardiosis is an abscess with dense neutrophilic infiltration and prominent necrosis. Granulation tissue usually surrounds the lesions. Neutrophils are able to phagocytose the organisms but fail to kill them efficiently. Cellmediated immunity play important role in control and elimination of Nocardiae [5].

There is no specific clinical manifestation of nocardiosis [6]. Pulmonary manifestation of nocardiosis includes chest pain, cough with or without, sputum, shortness of breath ,fatigue and reduced appetite [7]. Chest imaging findings in Nocardiosis includes pulmonary consolidation, irregular nodular or solitary irregular lung mass, interstitial reticular pattern, pleural effusion, or lymphadenopathy, but not definitive specific diagnostic feature. Our patient had productive cough and HRCT chest showed multiple nodular lesions in both lower zones, and cavitatory lesions more on left side.

Skin ans cutaneous manifestations occur as a result of secondary dissemination from systemic infection or secondary to hematogenous dissemination from a pulmonary focus. Skin involvement occurs in approximately $20 \%$ of patients with systemic nocardial infection [6). CNS nocardial infections may manifest with features of single cerebral abscess, extensive brain or spinal cord lesions, diffuse encephalitis and meningitis mimicking neoplasms, vasculitis and stroke $[8,9]$.

The cerebral imaging findings may vary from small to frank abscess formation, in which necrotic debris accumulates centrally, while the collagenous capsule is being formed. On T1weighted images, the abscess capsule stands out against the necrotic center and surrounding edema as an isointense to slightly hyperintense ring. On T2-weighted images the ring is consistently hypointense [10].

Identification of Nocardia pathogens is the only way for definitive diagnosis of this disease. The organism may be identified by $1 \%$ acidfast staining and species identification by culture from pus from skin lesions, sputum, broncho alveolar lavage, pleural fluid or drainage of pulmonary abscess. However in our laboratory we couldn't identify the Nocardia species. Nocardia bacteria grow slowly; therefore, it may require 4-week time to grow bacteria in culture, or it can remain undetected [5].

Combination of trimethoprim and sulphamethaxazole is the first line medication of choice and requires prolonged course upvto 612 months. In patients with CNS involvement atleast two drugs are recommended including Imipenem or Amikacin along with Cotrimoxazole. Our patient received cotrimaxazole, imipenem, amikacin in addition to the empirical ceftriaxone however she could not be revived. Alternative antimicrobial agents which can be used are meropenem, cefotaxime, minocycline, moxifloxacin, levofloxacin, linezolid, tigecycline and amoxicillin with clavulanicacid [11]. Previous reports have described Nocardiosis even in immunocompetent patients with predominantly single organ involvement [12]. Like our case it is exceptional to have Disseminated Nocardiosis in an apparently immunocompetent adult however we could not find out any definite evidence of immunosuppressed status from history and in 
hospital evaluation, still a remote possibility of some predisposition, which can't be ruled out.

\section{Conclusion}

Disseminated Nocardiosis is often misdiagnosed because of its rarity and nonspecific presentations and difficult identification. Mutations in Nocardia species may be responsible for its increasing incidence in immunocompetent individuals. High index of clinical suspicion, early microbiological detection and imaging study is required for the timely diagnosis and appropriate management of this rare disease to avoid fatal outcome.

\section{ACKNOWLEDGMENTS}

Declaration of Conflicting Interests: The authors declare that they have no conflict of interest.

Funding source: The authors received no third party funding for this study.

\section{REFERENCES}

1. Lerner PI. Nocardiosis. Clin Infect Dis 1996; 22:891-905.

2. Brown JM, McNeil MM. Nocardia, Rhodococcus, gordonia, actinomadura, streptomyces, and other aerobic actinomycetes. In: Murray PR, Baron EJ, Pfaller MA, et al. editors. Manual of Clinical Microbiology, $8^{\text {th }}$ edn. Washington, D.C: American Society for Microbiology; 2003:502-531.

3. Rodríguez-Nava V, Couble A, Devulder G, Flandrois JP, Boiron P, Laurent F. Use of PCRRestriction Enzyme Pattern Analysis and Sequencing Database for hsp65 GeneBased Identification of Nocardia Species. J Clin Microbiol 2006; 44:536-546.

4. Yu S, Wang J, Fang Q, Zhang J, Yan F. Specfic clinical manifestations of Nocardia: A case report and literature review. Exp Ther Med 2016; 12(4): 20212026.

5. Harrison's Principles of Internal Medicine 19th/e. Section 7: Miscellaneous bacterial infections, 199 Nocardiosis,Gregory A. Filice; 1084-1088.

6. Mootsikapun $\mathrm{P}$, Intarapoka B, Liawnoraset W. Nocardiosis in Srinagarind Hospital, Thailand: Review of 70 cases from 1996-2001. Int J Infect Dis. 2005; 9:154-158.

7. Kageyama A, Yazawa K, Ishikawa J, Hotta K, Nishimura K, Mikami Y. Nocardial infections in Japan from 1992 to 2001, including the first report of infection by Nocardia transvalensis. Eur J Epidemiol. 2004; 19:383-389.
8. Kennedy KJ, Chung KH, Bowden FJ, et al. A cluster of nocardial brain abscesses. SurgNeurol 2007; 68:43-49.

9. Kumar VA, Augustine D, Panikar D, et al. Nocardia farcinica brain abscess: Epidemiology, pathophysiology, and literature review. Surg Infect (Larchmt) 2014; 15:640-646.

10. Sud S, Buxi T, Anand I, Rohatgi A. Case series: Nocardiosis of the brain and lungs. Indian $\mathrm{J}$ Radiol Imaging 2008; 18: 218-21.

11. Wilson JW. Nocardiosis: Updates and Clinical Overview. Mayo Clin Proc 2012; 87(4):403-407

12. Chaudhari M, Renjen PN, Sardana R, Butta H. Nocardia Farcinica brain abcess in an immunocompetent old patient: Acase report and review of literature. Ann Indian Acad Neurol 2017; 20:399-402. 